\title{
Investigation of concrete compressive strength of existing buildings depending on number of core samples
}

\author{
Mevcut binalarda beton basınç dayanımının karot sayısına bağlı \\ değişiminin incelenmesi
}

\author{
Mehmet INEL ${ }^{1}$, Bayram Tanık ÇAYCI ${ }^{2 *}$, Hayri Baytan ÖZMEN ${ }^{3}$ \\ 1,2Department of Civil Engineering, Engineering Faculty, Pamukkale University, Denizli, Turkey. \\ minel@pau.edu.tr, bcayci@pau.edu.tr \\ ${ }^{3}$ Department of Civil Engineering, Engineering Faculty, Usak University, Uşak, Turley. \\ baytan.ozmen@usak.edu.tr
}

Received/Geliş Tarihi: 30.07.2018, Accepted/Kabul Tarihi: 13.12.2018

* Corresponding author/Yazıșılan Yazar

doi: 10.5505/pajes.2018.00236

Research Article/Araștırma Makalesi

\section{Abstract}

Concrete strength is one of the most critical parameters that affect the seismic performance of reinforced concrete constructions. One of the common methods to determine the concrete compressive strength is to take core samples from structural members. However, the number of taken core samples-based on the size of the construction-is important for reliable results, especially in old constructions. This study aims to investigate the possibility of determination of the concrete compressive strength values of existing buildings using lower number of core samples than the required number of cores. For this purpose, experimental results of core samples taken from 148 slightly or moderately damaged reinforced concrete buildings during 2011 Simav Earthquake. Concrete compressive strength values based on 15 different sets obtained by using 50\% and 70\% of the core samples of each building are compared. The compressive strength values calculated from the sets were compared with the average compressive strengths of all core samples to investigate accuracy of estimation of compressive strength with using lower number of core samples. The study also investigates whether there is a significant difference between samples taken from a single story (i.e. ground story) compared to the whole building. It is concluded that the use of $\% 50$ of the required core samples is possible for the rapid assessment or large-scale field investigation studies when the obtained concrete strength is equal to or greater than $8 \mathrm{MPa}$. However, additional core samples to complete $70 \%$ of the code required samples are required for concrete strength values lower than $8 \mathrm{MPa}$.

Keywords: Concrete compressive strength, Core, Reinforced concrete building

\section{Introduction}

Concrete compressive strength is one of the most important parameters affecting the seismic performance of reinforced concrete constructions [1]. Thus, the estimation of concrete compressive strength values as close as possible to actual values is of great importance for seismic performance evaluation of reinforced concrete buildings. Taking core samples is widely used to determine concrete compressive strengths of reinforced concrete buildings. However, determining the number of cores used to estimate the concrete compressive strength is a significant problem in old structures where production quality can vary greatly in terms of the story and/or members. In structures built using the hand casting technique, obtaining a certain concrete standard is difficult Concrete quality can be reduced due to the negligence in the
Öz

Beton basinc dayanımı betonarme yapıların sismik performansinı etkileyen en önemli parametrelerden birisidir. Taşıyıcı sistem elemanlarından karot numunesi alınması, basinc dayanımının tayininde kullanılan en yaygin yöntemlerden birisidir. Ancak yapı büyüklüğüne de bağlı olarak hesaplanan beton basınç dayanımı alınan karot sayısına göre değişkenlik gösterebilmektedir. Bu nedenle mevcut basınç dayanımının doğru șekilde tahmin edilebilmesi için optimum sayıda karot numunesi alınması büyük önem arz etmektedir. Gerçekleștirilen çalışmada bina mevcut beton dayanımının daha düşük sayıda karot numunesi ile tahmin edilmesinin mümkün olup olmadığı araștırılmıștır. Bu kapsamda Simav depremi sırasında az ve orta hasarl olarak belirlenen 148 binadan alınan karot numuneleri kullanılmıstır. Alınan karot numunelerinin \%50'si ve \%70'i rastgele seçilerek her bina için 15 farklı set olușturulmuștur. Olușturulan setlerden hesaplanan basınc dayanım değerleri ile tüm karot numuneleri için hesaplanan basınç dayanımları karşılaștırılarak daha az sayısa karot numunes alınması durumunda mevcut dayanımın ne ölçüde tahmin edilebildiğ incelenmiştir. Ayrıca beton basınç dayanımının katlara göre değişkenliği ve zemin kat gibi belirli bir katın bina basınç dayanımını ne ölçüde yansıttığı da incelenmiștir. Elde edilen sonuçlar incelendiğinde geniş ölçekli hızlı değerlendirme çalışmalarında ilgili yönetmeliklerce alınması gereken minimum karot sayısının \%50'sinin kullanımın ortalama dayanımı 8 MPa'dan yüksek binalar için mümkün olduğu değerlendirilmektedir. Ortalama basınc dayanımı $8 \mathrm{MPa}$ 'dan daha düşük binalar içinse gerekli minimum karot sayısının \%70'nin kullanılması mümkün görülmektedir

Anahtar Kelimeler: Beton basınc dayanımı, Karot, Betonarme binalar

curing of the concrete. Moreover, concrete quality may be lower at upper stories due to difficulties encountered in transportation to a higher level [2].

As well as all these uncertainties, some difficulties are encountered while taking core samples from residential buildings because it is a destructive method. Taking many concrete samples from existing buildings causes discomfort for the inhabitants and can be detrimental for the members. Therefore, determining the concrete compressive strength of the building by using a minimum number of core samples is important.

The requirements may change according to building codes. The usual requirement is to take at least 3 core samples for each story of the building (FEMA-356 [3], Eurocode8 [4], TEC-2007 [5]). However, special requirements may be permitted to 
minimize the discomfort for the inhabitants. Turkish Risky Building Detection Code [6] allows the use of concrete compressive strength values estimated by core samples taken from a single story for seismic risk evaluation studies. The purpose of Turkish Building Detection code is not performance assessment of buildings. It is used to determine whether the investigated building is risky or not. Thus, taking core samples only from specific story (the ground story for most of case) is acceptable process to be fast and inexpensive method. But taking core samples in specific story is also questionable whether it can reflect or not the concrete compressive strength of whole building.

This study aims to investigate the possibility of determination of the concrete compressive strength values of existing buildings using lower number of core samples than the required number of cores. For this purpose, experimental results of core samples taken from 148 damaged reinforced concrete buildings during 2011 Simav Earthquake as a part of joint project by Pamukkale University and the Disaster and Emergency Management Presidency [7] were used. The samples were taken from slightly and moderately damaged buildings as shown in Figure 1. The variation of determined concrete compressive strengths, depending on the number of core samples taken from reinforced concrete buildings are investigated. The study also evaluates the correlation of concrete samples taken from different stories and whether there was a significant difference between samples taken from a single story (i.e. ground story) compared to the overall structure.

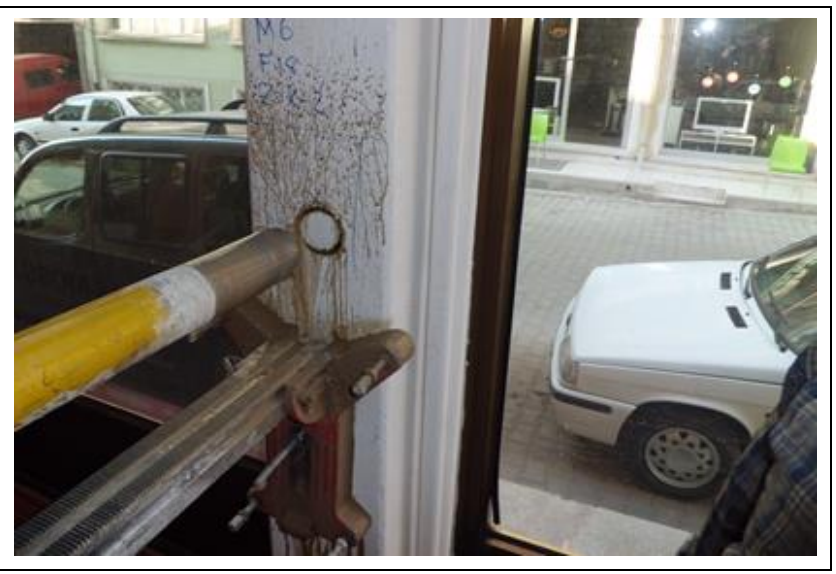

Figure 1: Concrete core sampling from the examined buildings.

\section{Simav earthquake}

An earthquake with a magnitude of 5.7 (ML) has struck Simav, Kutahya located in the western part of Turkey on May 19, 2011 at 20:15 (GTM) (Figure 2). The earthquake indirectly caused 3 casualties and more than 70 injuries [9]. The ground motion has been strongly felt by approximately 135.000 people and caused observable damage around a maximum of $25 \mathrm{~km}$ radius from the epicenter. Although the magnitude of earthquake is moderate, the effects of the earthquake on the structures are serious [10]. The number of damaged and collapsed buildings around Simav is given in Table 1. More detailed information about the damages may be obtained from the study by Inel et al., 2013 [11].

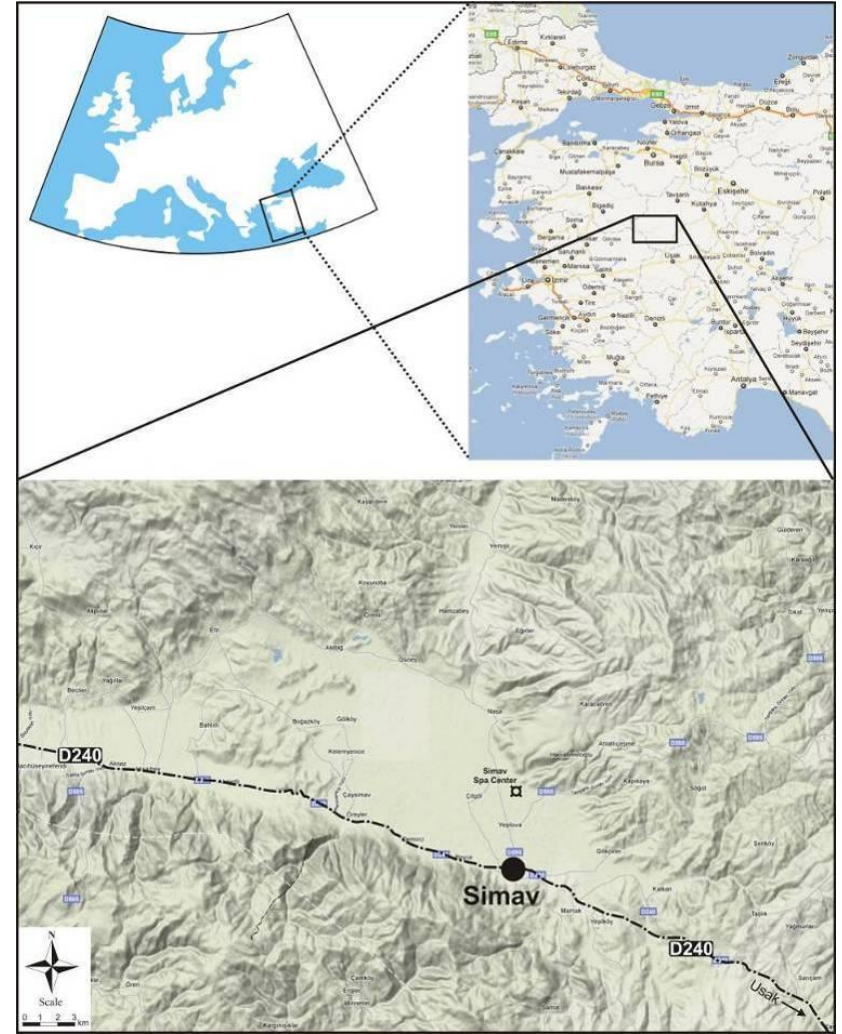

Figure 2: Location map of the study area [8].

Table 1: The number of damaged and collapsed buildings around Simav.

\begin{tabular}{cccccc}
\hline & \multicolumn{5}{c}{ Damage State } \\
\hline Region & Collaps & Heavy & Moderate & Light & None \\
Simav City & 5 & 331 & 261 & 1531 & 2265 \\
$\begin{array}{c}\text { Simav Towns \& } \\
\text { Villages }\end{array}$ & 104 & 929 & 125 & 2759 & 3254 \\
Hisarclk & 3 & 79 & 6 & 337 & 64 \\
Saphane & 2 & 46 & 7 & 290 & 153 \\
Pazarlar & 1 & 56 & 10 & 255 & 43 \\
\hline
\end{tabular}

\section{Methodology}

Compressive strength of reinforced concrete buildings was investigated using core samples taken from 148 buildings damaged at different levels during 2011 Simav Earthquake. In the current Turkish Earthquake Code (TEC-2007) [5] the minimum number of core samples is specified based on knowledge level that accounts the uncertainty in the collection of as-built building data. Three knowledge levels are considered in the TEC-2007 as "Limited", "Moderate" and "Comprehensive" as specified in FEMA-356 [3] or similar documents. Core samples for 148 reinforced buildings in Simav were taken based on "Moderate" knowledge level specified in TEC-2007 that requires minimum 3 core samples from each story. Concrete compressive strength values were calculated for 15 different sets, obtained by using the $50 \%$ and $70 \%$ of the total number of samples for each building. There is a high number of possibilities to select 15 core sample sets. For example, in a building where 18 samples were taken, 9 of these samples were randomly selected to form 13 different sets for $70 \%$ of core samples. Similarly, 15 different sets were formed by including 9 random samples for $50 \%$ of samples. The average and standard deviation values obtained from all samples were compared with those obtained from 15 different sets using $70 \%$ and $50 \%$ samples. The main reason of creating 
these sets is to investigate possibility of determination of the concrete compressive strength of whole building reasonably by using lower number of core samples taken from investigated buildings ( $50 \%$ and $70 \%$ for this case).

Some building codes may permit using the concrete compressive strength values estimated by the core samples taken from a single story for seismic risk evaluation [6]. As it is a destructive method, taking core samples from a single story is appealing to minimize the discomfort. Therefore, in addition to the effect of the number of core samples, the correlation of the strength values obtained from samples taken from different stories across the overall construction is also investigated. For this purpose, the average concrete strength values obtained using core samples taken from different stories are compared to the value obtained using core samples from the whole building.

\section{Building data}

The determination of compressive strength of the concrete is especially important for existing buildings that are constructed regardless of seismic design principles. Also, in many existing buildings in Turkey, the used concrete was prepared at the construction site with handmade techniques preventing a standard outcome. These types of buildings constitute the majority of the risky buildings that need seismic risk assessment. Therefore, the investigation on the concrete strength variability using the existing buildings is important. The buildings slightly or moderately damaged after May 19, 2011 Simav earthquake [10], offers an important possibility for such an investigation.

The majority of reinforced concrete buildings examined in the study were low and mid-rise residential buildings built using the handmade concrete. These buildings were constructed before the 1998 Turkish Earthquake Code [12] which is the first comprehensive code in Turkey in terms of many seismic resistance principles. As the majority of investigated buildings were built in 1980's and at the beginning of 1990's, it is expected that the characteristic concrete compressive strength value is $14 \mathrm{MPa}$ that corresponds to B160 concrete for residential buildings.

The distribution of the number of buildings with respect to the number of stories is shown in Figure 3. The figure obviously shows that the majority of buildings have 4 or 5 stories.

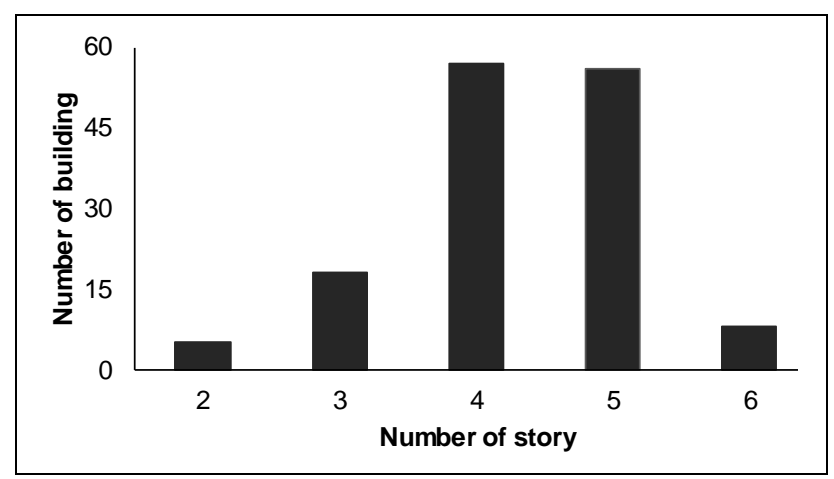

Figure 3: Distribution of the number of story of the investigated building set.

The distribution of average concrete compressive strengths of 148 damaged buildings is shown in Figure 4 using three core samples per each story. When the figure is examined, it is observed that the average concrete compressive strength value of many buildings was below $10 \mathrm{MPa}$. This seems to be an expected observation considering the date of construction of the buildings and hand-mixed concrete use.

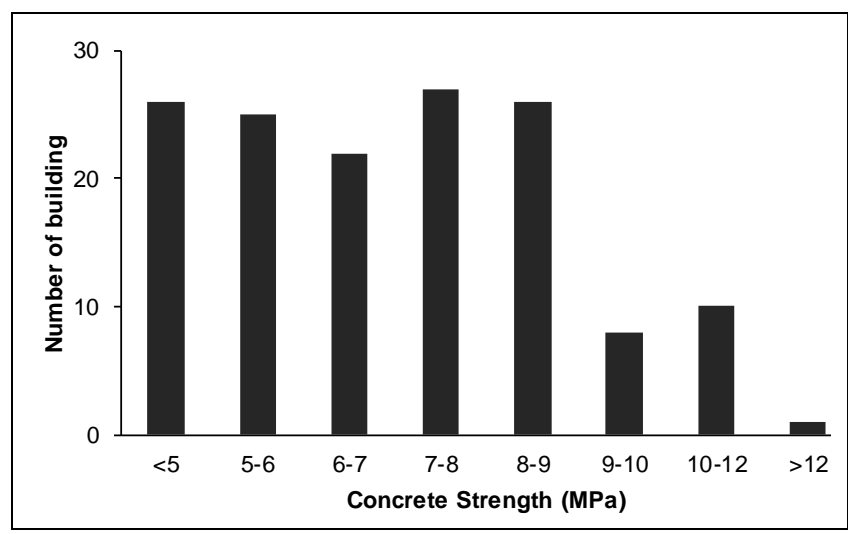

Figure 4: Distribution of average concrete compressive strengths.

\section{Analysis results}

Compressive strength values of each building were determined based on 3 core samples for each story. Core samples were taken and tested according to TS 10465 (1992) [13] as stated in TEC-2007. Compressive strength test results of each core sample were corrected with height/dimension ratio coefficient defined in ASTM C42/C 42M-99 standard [14]. Concrete compressive strength of buildings was determined by subtracting the standard deviation from the average strength of core samples.

Since this study aims to evaluate the possibility of determining the concrete compressive strength of buildings using lower number of cores than the code requirements. For this purpose, the concrete strength of randomly obtained 15 different sets using $50 \%$ and $70 \%$ of required core samples were compared to the concrete strength of the building obtained using 3 core samples from each story. The random selection is used for the effect of core sample location on the concrete strength while $50 \%$ and $70 \%$ of core samples are used to evaluate the effect for the number of samples. Besides, the concrete strength values of core samples taken from a single story is also compared to the building concrete strength values.

Figure 5 plots the variation of concrete compressive ratio of randomly selected 15 sets for average compressive strength of each building. The horizontal axis represents the concrete strength ranges of the buildings; 4-6 MPa, 6-8 MPa, 8-10 MPa and greater than $10 \mathrm{MPa}$. Therefore, each horizontal point includes 15 randomly selected data set times number of buildings within the considered concrete strength. Although there are buildings with concrete strength lower than $4 \mathrm{MPa}$, they are not considered as meaningful. The vertical axis plots the ratio of compressive strength of randomly selected samples to compressive strength of the building considering all data. Figure 5(a) and Figure 5(b) show the variation for 50\% and $70 \%$ of samples, respectively. The box plot borders illustrate average minus standard deviation, average and average plus standard deviation values. Figure 5 indicates that both $50 \%$ and $70 \%$ of core sample ratios have similar trend for concrete strength estimates. The compressive strength ratios range between 0.35 and 2.62 for $50 \%$ of core samples while the ratios change from 0.57 and 1.84 for $70 \%$ of core samples. A significant scatter is obvious for the lower concrete strength 
values. The scatter decreases as the concrete strength values and number of core samples increase. The decrease in variation is more obvious for samples having concrete compressive strength values higher than $8 \mathrm{MPa}$. Although there is not a significant change in the average concrete compressive strength values, it can be seen that the standard deviation values (scatter) decreases approximately up to $100 \%$ for both groups as the concrete compressive strength values increase.
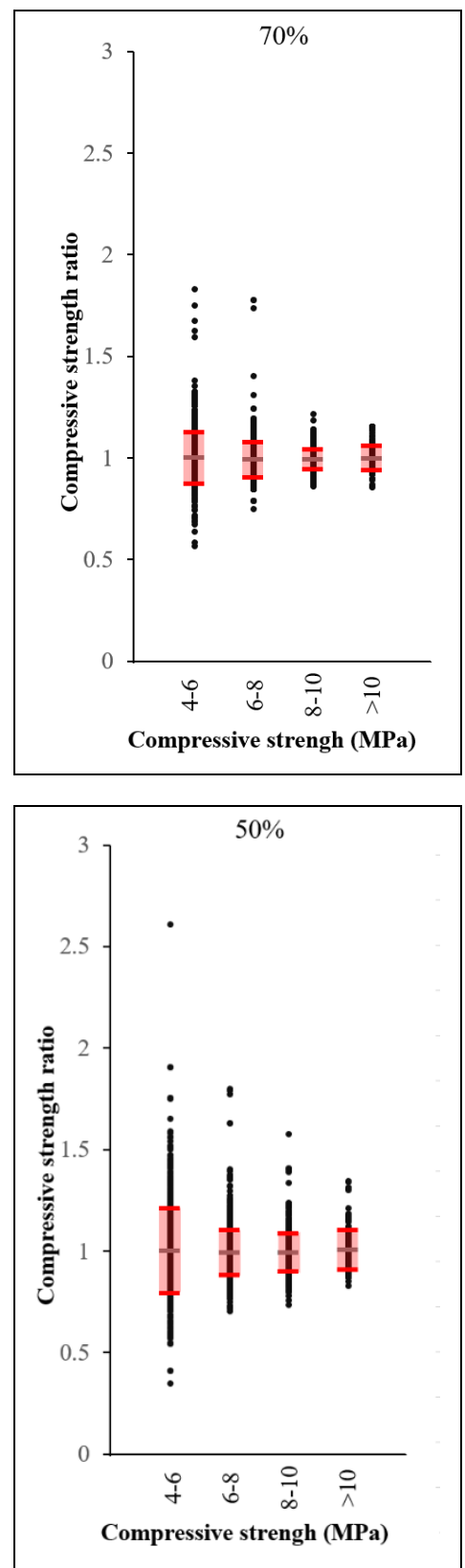

Figure 5: Concrete compressive strength ratios of $50 \%$ and $70 \%$ of sets to the compressive strength of building with all samples.

Assuming that $15 \%$ deviation from the building concrete strength using the required number of core samples is reasonable, the concrete strength estimates using lower number of core samples are evaluated. Figure 6 compares the compressive strength ratio of $50 \%$ and $70 \%$ of core samples with building averages. Red lines indicate the 0.85 and 1.15 values of compressive strength ratios. Table 2 lists the percentage of compressive strength ratios within the 0.85 and 1.15 values. The estimation success of $50 \%$ and $70 \%$ of core samples with $15 \%$ deviation is $80 \%$ and $94 \%$ respectively. It is obvious that the deviation is more significant for the lower building concrete strength values. Therefore Table 2 also illustrates the estimation success for the concrete strength values lower than $8 \mathrm{MPa}$ and $8 \mathrm{MPa}$ or higher than $8 \mathrm{MPa}$, separately. The use of lower number of core samples depends on the building concrete strength. When the building concrete strength is equal to or higher than $8 \mathrm{MPa}$, both $50 \%$ and $70 \%$ of the required core samples provide reasonable result; $90 \%$ and $98.7 \%$ of estimates are within $15 \%$ deviation limits for $50 \%$ and $70 \%$ of the required core samples, respectively. However, the percentages of the concrete strength estimates within $15 \%$ deviation limits are $70 \%$ when $50 \%$ of the core samples is used. It is recommended that the $\% 50$ of the required core samples may be used for the rapid assessment or large-scale field investigation studies when the obtained concrete strength is equal to or greater than $8 \mathrm{MPa}$. However, additional core samples to complete $70 \%$ of the code required samples are required for concrete strength values lower than $8 \mathrm{MPa}$.
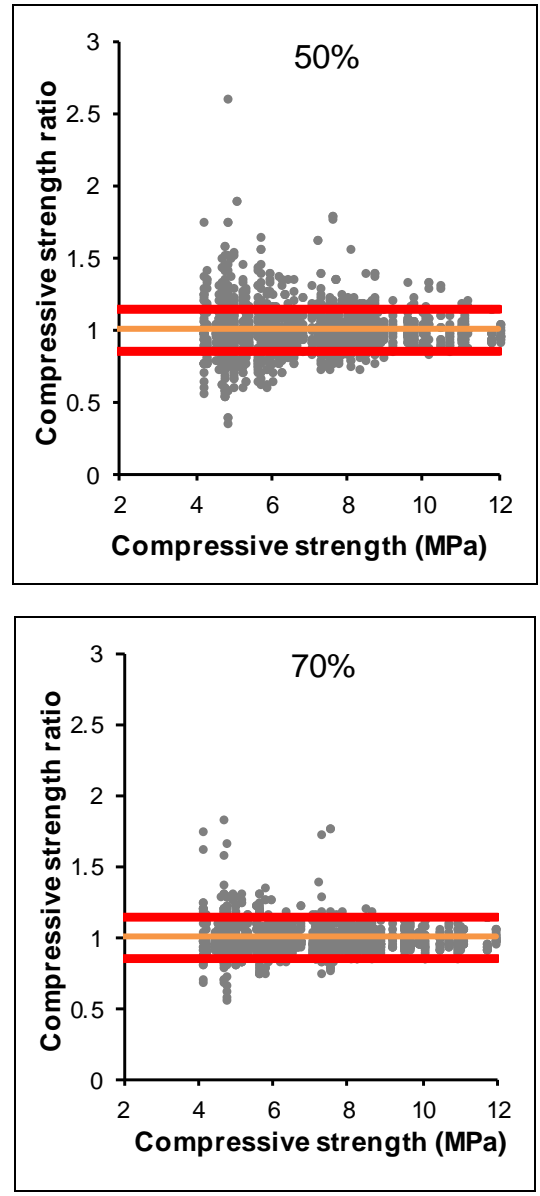

Figure 6: Concrete compressive strength ratios of $50 \%$ and $70 \%$ of sets to the compressive strength of building with all samples.

Table 2: Percentage of concrete strength estimates within $\% 15$ deviation.

\begin{tabular}{ccc}
\hline Concrete Strength & $50 \%$ & $70 \%$ \\
\hline$<8 \mathrm{MPa}$ & $70 \%$ & $90.5 \%$ \\
$\geq 8 \mathrm{MPa}$ & $90 \%$ & $98.7 \%$ \\
Average & $80 \%$ & $94.5 \%$ \\
\hline
\end{tabular}


As mentioned in Section 2, some building codes may permit the use of strength values estimated by the core samples taken from a single story that is usually the ground story for most cases [6]. Additionally, concrete compressive strength may be lower at upper stories due to difficulties encountered in transportation to a higher level for old buildings constructed without concrete pumps. Thus, the concrete strengths at the upper stories may be expected to be lower than the building average values. Moreover, when the inferior construction capabilities and the time needed to wait for stripping slab formwork is considered, erection of a multi-story building may last for many months. Seasons may change during this time and the changing temperature and the weather conditions may affect the curing and strength of the concrete. Therefore, the change of concrete strength with respect to story levels may be of attention.

Figure 7 plots the ratio of concrete strength of ground floor (Figure 7a) and top floor (Figure 7b) to the building concrete strength. Significant and similar scatter is obvious for both ground and top stories. Besides the scatter is independent from the building concrete strength values. The concrete strength based on core samples from a single story (ground or top) ranges approximately between $47 \%$ and $175 \%$ of the concrete strength based on samples taken from throughout the building. The percentages of concrete strength values within the $15 \%$ deviation range are 59\%, 57\% for ground story and top story, respectively. Both ground and top stories have similar scatter.

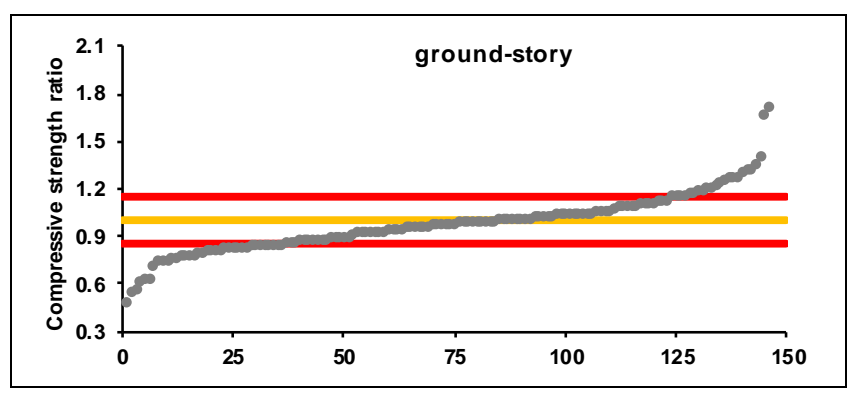

(a)

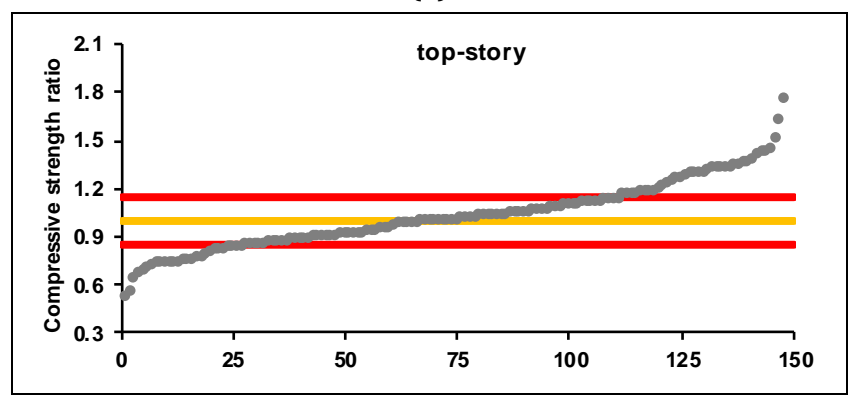

(b)

Figure 7: Distribution of concrete compressive strength in ground story. (a): Top story, (b): Versus average concrete compressive strength for the building (each data on horizontal axis represent a building with increasing compressive strength ratio).

Considering the scatter and the values abovementioned, it is hard to say that the concrete compressive strength values based on a single-story core samples are reliable. The outcomes indicate that taking core samples from a specific story as described in Turkish Risky Buildings Detection Code [6] may be inadequate to reflect the concrete compressive strength of building. Instead of taking core samples from a single story, the use $50 \%$ or $70 \%$ of the code required core samples from all stories is much more effective and reliable.

Figure 8 illustrates the ratio of concrete compressive strength based on the specific story to the compressive strength values based on all stories. There is no specific tendency for the ratio of individual story concrete strength and building concrete strength. The ratios vary between 0.5 and 1.75 . The variation is almost similar throughout the building height. It should be noted that the number of 5-story buildings is limited. Therefore, the variation at the fifth story level seems to be low. The variability of both curing conditions and the use of unstandardized mixed in place concrete are the main reasons contributing to these differences.

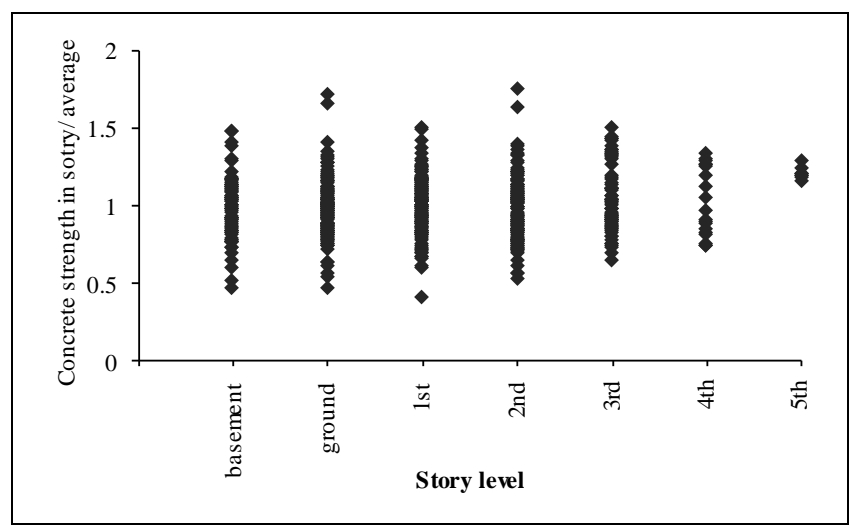

Figure 8: Ratio of concrete compressive strength in a story to the building average value.

\section{Summary and conclusions}

Concrete compressive strength is one of the most critical parameters that affect the seismic performance of reinforced concrete buildings. Therefore, accurate determination of this value is crucial for seismic evaluation. This study investigated the possibility of determination of the concrete compressive strength of existing buildings using lower number of core samples. The experimental results of core samples taken from 148 slightly or moderately damaged reinforced concrete buildings during 2011 Simav Earthquake as a part of joint project by Pamukkale University and the Disaster and Emergency Management Presidency was used. As the majority of investigated buildings were built in 1980's and at the beginning of 1990's, it is expected that the characteristic concrete compressive strength values are $14 \mathrm{MPa}$ that corresponds to B160 concrete for residential buildings. Concrete for these buildings was generally produced using hand-mixed techniques. Concrete compressive strength values of samples were determined by taking 3 core samples from each story as required in Turkish Earthquake Code (TEC-2007) for the moderate level knowledge. Fifteen sets were formed by randomly selecting $50 \%$ and $70 \%$ of number of the core samples taken and the obtained compressive strength values were compared to the compressive strength value of the building based on all core samples. The results are summarized as below:

- Majority of buildings has concrete compressive strength values lower than $10 \mathrm{MPa}$. Considering the fact that concrete was prepared using handmade techniques without reference to any standard during the construction of these buildings, low concrete compressive strength values are predictable, 
- The estimates of concrete strength values using $50 \%$ and $70 \%$ of the required core samples illustrates that the variation in concrete compressive strength estimates improve as the number of core samples increases,

- The use $70 \%$ of required number of core samples in the seismic codes can successfully estimate the average compressive strength of buildings with $15 \%$ deviation for all concrete strength values obtained in the study (4-12 MPa). However, the use of $50 \%$ of the required samples provides successful estimated for the concrete strength values equal to or higher than 8 $\mathrm{MPa}$,

- It is recommended that the use of $\% 50$ of the required core samples is possible for the rapid assessment or large-scale field investigation studies when the obtained concrete strength is equal to or greater than $8 \mathrm{MPa}$. However, additional core samples to complete $70 \%$ of the code required samples are required for concrete strength values lower than $8 \mathrm{MPa}$,

- While the forecast success of $70 \%$ of core samples with $15 \%$ aberration rate, it is calculated $59 \%$ when only base-story considered,

- Thus, taking less number of core samples from wholestories is better approach then considering singlestory,

- When the average compressive strength values for each individual story are compared to the average concrete strength of the building, there is no specific tendency. The variability of both curing conditions and the use of unstandardized mixed in place concrete are considered to be the main reasons contributing to the variation,

- Considering the scatter and the values observed in this study, it is hard to say that the concrete compressive strength values based on a single-story core samples are reliable. The outcomes indicate that taking core samples from specific story as described in Turkish Risky Buildings Detection Code [6] may be inadequate to reflect the concrete compressive strength of building. Instead of taking core samples from a single story, the use $50 \%$ or $70 \%$ of the code required core samples from all stories is much more effective and reliable.

\section{Acknowledgement}

The core sample values used in this study are taken from study by Inel et al. (2011) which is supported financially by Republic of Turkey Prime Ministry Disaster and Emergency Management Presidency

\section{References}

[1] Ozmen, HB, Inel M, Meral E. "Evaluation of the main parameters affecting seismic performance of the RC buildings". Sadhana-Academy Proceedings in Engineering Science, 39(2), 437-450, 2014.

[2] Binici H, Cagatay I, Kaplan H. "Experimental Study on Effect of Various Factors on Compressive Strength of Concrete". Pamukkale University Journal of Engineering Sciences, 6(3), 203-209, 2000.

[3] FEMA-356. "Prestandart and commentary for the seismic rehabilitation of buildings". Federal Emergency Management Agency, Washington, 2000.

[4] Cen. "Eurocode 8: Design of structures for earthquake resistance Part 3: Assessment and retrofitting of buildings." Comité Européen de Normalisation, Bruxelles, 2004.

[5] Turkish Earthquake Code-TEC 2007. "Specifications for buildings to be built in seismic areas". Ministry of Public Works and Settlement, Ankara, Turkey, 2007 (in Turkish).

[6] Turkish Risky Buildings Detection Code-TRBDC. "The law of Transformation Areas under the Disaster Risks (Law No. 6306)". Ministry of Environment and Urbanisation, Ankara, Turkey, 2012 (in Turkish).

[7] Inel M, Un H, Ozmen HB, Akyol E, Cayci BT, Ozcan G. "Investigation of the feasibility of retrofitting the moderately damaged buildings in Simav region and surroundings". Report for Disaster and Emergency Management Presidency, Denizli, Turkey, 2011.

[8] Google. "Google Maps Services". http://maps.google.com/, (08.11.2012).

[9] Disaster and Emergency Management Presidency (DEMP). "Building damage results in Kutahya". Ankara, Turkey, 2011.

[10] Ozmen, HB, Inel M, Akyol E, Cayci BT, Un H. "Evaluations on the Relation of RC Building Damages with Structural Parameters after May 19, 2011 Simav (Turkey) Earthquake". Natural Hazards, 71(1), 63-84, 2014.

[11] Inel, M, Ozmen, HB, Akyol, E. "Observations on the building damages after 19 May 2011 Simav (Turkey) earthquake". Bulletin of Earthquake Engineering, 11 (1) 255-283, 2013.

[12] Turkish Earthquake Code. "Specifications for buildings to be built in seismic areas". Ministry of Public Works and Settlement, Ankara, 1998 (in Turkish).

[13] TS 10465 "Test method for concrete- obtaining samples and determination of compressive strength in hardened concrete in structures and components (Destructive Method)". Turkish Standards Institution, Ankara, 1992.

[14] ASTM C42/C 42M-99. "Standard Test Method for Obtaining and Testing Drilled Cores and Sawed Beams of Concrete1". ASTM, USA, 1999. 